\title{
IRRITANT AND ALLERGIC CONTACT DERMATITIS - SKIN LESION CHARACTERISTICS
}

\author{
Gaby Novak-Bilić ${ }^{1}$, Majda Vučićc ${ }^{2,3}$, Iva Japundžićc ${ }^{3,4}$, Jelena Meštrović-ŠStefekov ${ }^{4}$, \\ Sandra Stanić-Duktaj ${ }^{1}$ and Liborija Lugović-Mihić ${ }^{3,4}$ \\ ${ }^{1}$ Dermatology and Venereology Unit, Zabok General Hospital, Zabok, Croatia; \\ ${ }^{2}$ Department of Pathology, Sestre milosrdnice University Hospital Center, Zagreb, Croatia; \\ ${ }^{3}$ School of Dental Medicine, University of Zagreb, Zagreb, Croatia; \\ ${ }^{4}$ Department of Dermatovenereology, Sestre milosrdnice University Hospital Center, Zagreb, Croatia
}

\begin{abstract}
SUMMARY - Contact skin lesions may be the consequences of contact with various irritants or allergens, or due to other factors (e.g., UV radiation, microbials), intrinsic factors (e.g., in autoimmune responses), or even their combination. There are many substances related to irritant contact dermatitis (CD), causing irritant or toxic effects, e.g., chemical and physical agents, plants, phototoxic agents, airborne irritants, etc. Impaired barrier function (e.g., aberrancies in epidermal $\mathrm{pH}$ buffering capabilities) also participates by promoting bacterial biofilms and creating an environment favoring sensitization. Development of allergic CD skin lesions includes complex immune pathways and inflammatory mediators, influenced by both genetic (predominantly filaggrin mutations) and environmental triggers. In the pathogenesis of allergic $\mathrm{CD}$, antimicrobial peptides play a prominent role; they are produced by various skin cells (e.g., keratinocytes, sebocytes) and move to inflamed lesions during an inflammation process. Also, in allergic CD skin lesions, the skin shows different types of immune responses to individual allergens, although clinical manifestations do not depend on the causative allergen type, e.g., nickel stimulates immune activation primarily of the Th1/Th17 and Th22 components. Also important are alarmins, proteases, immunoproteomes, lipids, natural moisturizing factors, tight junctions, smoking, etc. We expect that future perspectives may reveal new pathogenetic factors and scientific data important for the workup and treatment of patients with CD.
\end{abstract}

Key words: Dermatitis, allergic contact; Dermatitis, irritant; Skin inflammation; Etiopathogenesis; Immunohistochemistry; Histology; Factors

\section{Introduction}

Contact dermatitis (CD) is an inflammatory skin disease caused by chemicals or metal ions that exert irritant (toxic) effects, or by small reactive chemicals (contact allergens) that modify proteins and induce immune responses (predominantly by $\mathrm{T}$-cell response $)^{1}$. Consequently, CD may manifest as irritant $\mathrm{CD}$ and allergic $\mathrm{CD}$, which may occur in acute or chronic forms.

Correspondence to: Prof. Liborija Lugović-Mibic, MD, PhD, Department of Dermatovenereology, Sestre milosrdnice University Hospital Center, Vinogradska c. 29, HR-10000 Zagreb, Croatia E-mail: liborija@gmail.com

Received March 13, 2018, accepted June 27, 2018
Irritant $\mathrm{CD}$ is a nonspecific skin response to direct chemical skin damage and/with releasing inflammatory mediators, while allergic CD is a delayed hypersensitivity reaction (type IV) to allergens, which includes immune responses (due to the interaction of $T$ cells and cytokines $)^{1}$. In differentiating the two diseases, it is pointed out that in irritant CD there are no immune reactions; no prior exposure to any substance (sensitization) is required; and most individuals exposed to such (usually aggressive) substance manifest a similar reaction ${ }^{2}$. Thereby, contact skin lesions may be the consequences of contact with various irritants or allergens, or due to other factors (e.g., UV radiation, microbials), intrinsic factors (not always well-defined stimuli, e.g., in autoimmune responses), or even their 
combination $^{3-11}$. When the occurrence of irritant $\mathrm{CD}$ and allergic $\mathrm{CD}$ is related to work activities, possible occupational CD may occur, related to different workplace factors (e.g., alcohol-based disinfectants and detergents, latex gloves $)^{6,9,11}$.

Irritant $\mathrm{CD}$ and allergic $\mathrm{CD}$ are relatively frequent dermatoses. Irritant $\mathrm{CD}$ is more common than allergic $\mathrm{CD}$. Although the incidence and prevalence of allergic $\mathrm{CD}$ in the general population are not precisely estimated, the prevalence of allergic $\mathrm{CD}$ is considered to be $15 \%$ to $25 \%{ }^{1}$.

\section{The Pathomechanisms of Contact Dermatitis}

When irritant $\mathrm{CD}$ lesions occur after exposure to a substance (even in small concentrations), effects may accumulate due to repeated influence commonly leading to chronic skin damages and skin lesions. Irritant CD may manifest in a form of acute and chronic lesions. There are many substances related to irritant $\mathrm{CD}$, caused by their irritant or toxic effects, e.g., chemical agents, physical agents, plants, phototoxic agents, airborne irritants, etc. ${ }^{1,2}$. Thus, skin lesions may be caused by different chemical agents (alkaline and acid solutions, organic solvents, tensides, croton oil), physical agents (UV radiation, $x$-rays, other ionizing radiation, laser rays, heat, cold and mechanical factors), food stuffs (e.g., asparagus, mustard, fruit juices), plants (e.g., agave, anemones, many others) and chemical warfare agents ${ }^{4-11}$. Contact skin lesions due to phototoxic agents are also possible. An irritating impact of the environment resulting from airborne irritants may also occur; irritating dusts or fumes can damage uncovered skin (especially the face), causing edema and blisters.

Chronic irritant CD may be induced by any substance causing acute irritant CD that, when in small concentrations, can accumulate effects causing chronic skin damages (even water, in cases of frequent hand washing, working in water, taking shower, bathing, etc. $)^{2}$. Consequently, it gradually changes, damaging and eliminating the skin protective barriers, particularly the protective lipid film on the surface of the horny layer, the appertaining acid $\mathrm{pH}$ of that layer and the very horny layer itself ${ }^{12-14}$.

On the other hand, in allergic $\mathrm{CD}$, skin lesions are induced by immune reactions and by sensitization to some substance (allergen) mediated by $\mathrm{T}$ cells, occur- ring through the sensitization (afferent) phase and the elicitation (efferent) phase. The results of patch test, used for checking and proving the delayed hypersensitivity reaction (type IV) are the most important diagnostic indicators in differentiation between irritant and allergic $\mathrm{CD}^{2}$. Various substances can be allergens, particularly metal salts which interact weakly with skin proteins and thus form complexes. At the first epicutaneous contact (the sensitization phase), the haptens stimulate keratinocytes to express adhesion molecules (ICAM-1), proinflammatory cytokines (IL-1- $\alpha$, IL-1 $\beta$, TNF- $\alpha$, IL-6) and chemokines (IP10, MCP-1, RANTES, CCL18) ${ }^{15-18}$. The epidermal Langerhans cells then take over and ingest the neoantigen, process it, express MHC class I and II molecules, and migrate to the regional lymph nodes where they present the antigen to naive $\mathrm{T}$ cells ${ }^{2}$.

It turned out that, in allergic $\mathrm{CD}$, keratinocytes secrete proinflammatory cytokines and chemokines that activate epidermal Langerhans cells and dermal vascular endothelial cells, which also express adhesion molecules and enable extravasation of the sensitized $\mathrm{T}$ cells (CD8, $\operatorname{Tr} 1)$, mastocytes, basophils and immunocytes $^{19,20}$. During the next contact with the same hapten, in the dermis, the antigen-presenting cells (APCs) present the neoantigen to the memory CD8+ lymphocytes, which develop the effector cytotoxic $\mathrm{T}$ lymphocyte (CTL) function. They bind with the keratinocytes expressing pMHC I and secreting interferon- $\gamma$ $(\mathrm{IFN}-\gamma$ ). The IFN- $\gamma$ (secreted from the CTLs and from the activated macrophages) stimulates the expression of Fas molecules on keratinocytes and this (IFN- $\gamma$ ), in turn, binds the FasL expressed by the CTLs, which leads to apoptosis. In the final phase, IFN- $\gamma$ stimulates mastocytes and basophils to release lytic mediators; it also stimulates vasodilators (e.g., histamine) and chemokines to enable further infiltration of cells and amplification of an inflammatory response $^{19,20}$. Within days, the macrophages migrate to the lymph nodes, where they express co-stimulatory molecules (CD80/86), present the antigen/allergen to the lymphocytes expressing late integrins [very late antigen (VLA)], 'homing' receptors (CD44), while also presenting the third infiltration wave and triggering an adaptive immune response $\mathrm{e}^{1,2,21}$.

Thus, development of allergic CD skin lesions includes complex immune pathways, influenced by both genetic and environmental triggers ${ }^{14}$. There are promi- 
nent roles of genetic variations and mutations (predominantly filaggrin mutations) and impaired barrier function (e.g., aberrancies in epidermal $\mathrm{pH}$ buffering capabilities), which may promote bacterial biofilms and create an environment favoring sensitization ${ }^{13,22,23}$. Regarding genetics, according to research data, filaggrin mutations (R501X, 2282del4, and R2447X) were identified in $16.9 \%$ of patients with hand eczema and were significantly associated with skin lesions (skin fissures on the fingers and heels).

Besides individual's predisposition, in inflammatory skin diseases the lesion development process and involved factors (including cytokines and immune cells) depend on the trigger ${ }^{3}$. Also important are antimicrobial peptides and alarmins, skin tight junctions, natural moisturizing factors, immunoproteomes, proteases, lipids, smoking, etc. ${ }^{24,25}$.

For allergic $\mathrm{CD}$ also important is how the allergens pass through the cell membrane channels, depending on allergen type. For example, in the skin lesions occurring due to nickel allergy, the water-permeable nickel salts can pass through the cell membrane channels by using ion exchange and, together with other molecules (e.g., proteins, amino acids), be incorporated in the cell. It has also been observed that in an immune response to nickel allergy, Th1 cells are more dominant than Th2 cells ${ }^{26}$.

Of the other factors involved in the pathogenesis of allergic $\mathrm{CD}$, there is the role of antimicrobial peptides (AMPs) produced by various skin cells (e.g., keratinocytes, sebocytes) moving to the inflamed lesion area during an inflammation process. As the AMPs act as protective antimicrobial barrier protecting the skin from bacterial and viral infections, they are called alarmins (because of their 'alarming' function and participation in inherent and acquired immune responses) ${ }^{24,27}$. Also, the AMP expression is regulated with the microbial factor and inflammatory cytokines. Some AMPs are generated if needed [as human $\beta$-defensin (HBD) HBD-1 and HBD 2 as cathelicidin $]^{27}$.

It has been confirmed that in inflamed CD lesions, skin tight junction proteins are often affected ${ }^{3}$. Thus, impaired barrier function is related to tight junctions, which form a barrier in the epidermal granular cell layer and are involved in keratinocyte proliferation, differentiation, cell-cell adhesion, and apoptosis.

It is also important that in irritant CD, occlusion decreases the skin barrier function and significantly enhances the irritant-induced barrier damaging effects. Also, according to research data, in irritant-exposed fields the natural moisturizing factor values were significantly decreased compared to non-exposed fields, indicating that occlusion enhanced decrease in the natural moisturizing factor ${ }^{12}$.

Also, $\mathrm{CD}$ is characterized by barrier disruption and inflammation, similar to atopic dermatitis (AD) and psoriasis, with unique epidermal signatures and common inflammatory pathways identified by transcriptomic profiling ${ }^{28}$. Proteomic profiling in subjects with both $\mathrm{CD}$ and $\mathrm{AD}$ identified additional dysregulated proteins (compared to subjects with either condition alone), indicating an exacerbated inflammation reaction. Unique serum proteomic signatures have been identified that may distinguish between inflammatory skin diseases $(\mathrm{CD}, \mathrm{AD})$ despite similar epidermal barrier disruption and epithelial inflammation ${ }^{28}$.

\section{Clinical Manifestations of Contact Dermatitis}

Clinically, irritant CD can occur as an acute or chronic disease. Lesions may occur anywhere but commonly appear on the hands ${ }^{2}$. Acute irritant CD is typically characterized by erythema, blisters, pustules, hemorrhage, crusts, scales and erosions, and also with pruritus or even pain (Fig. 1). Skin lesions in acute irritant $\mathrm{CD}$ are predominantly sharply bordered in the areas of contact (distant spread does not occur) and usually asymmetric.

On the other hand, chronic irritant CD is characterized by diffuse or localized lesions with typically poorly defined erythematous scaly patches and plaques, dryness of skin, lichenification and desquamation ${ }^{2}$. Irritant skin lesions commonly occur on the back of the hands and forearms (palms have greater intrinsic resistance). The disease is often asymmetric, with the dominant hand more affected. As the disease persists, lichenification and fissures develop, with possible nail damage (paronychia with nail dystrophy, pitting, oil spots, etc.). Distant reactions usually do not occur and the disease is usually limited to the areas of repeated contact.

In allergic $\mathrm{CD}$ skin lesions, there are several different clinical phases, i.e. erythematous phase with an unsharply delineated erythema or skin edema; and madidans phase characterized by erosions and moistening (Fig. 2). In the next stage, crusts appear, followed 


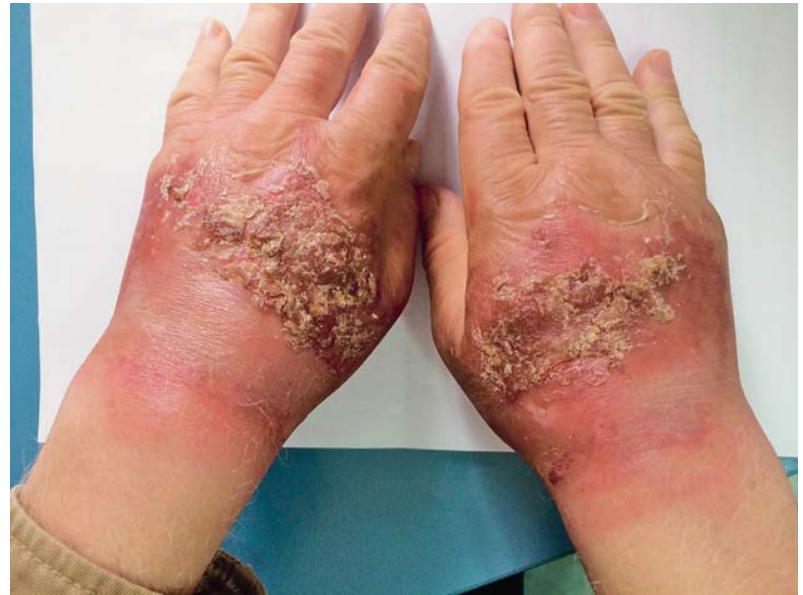

Fig. 1. Acute irritant contact dermatitis with impetiginization.

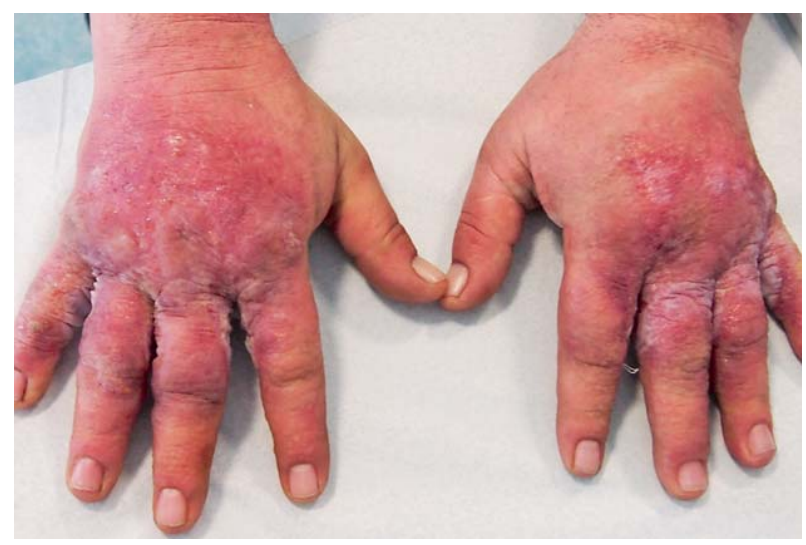

Fig. 2. Acute allergic contact dermatitis.

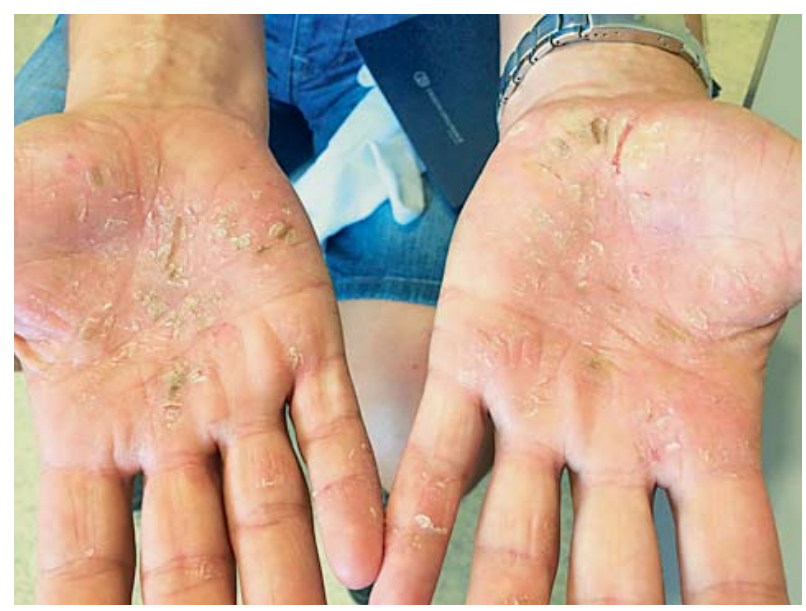

Fig. 3. Chronic irritant contact dermatitis.

by the final, squamous stage, when the horny layer repairs itself. Acute allergic CD develops after 24-48

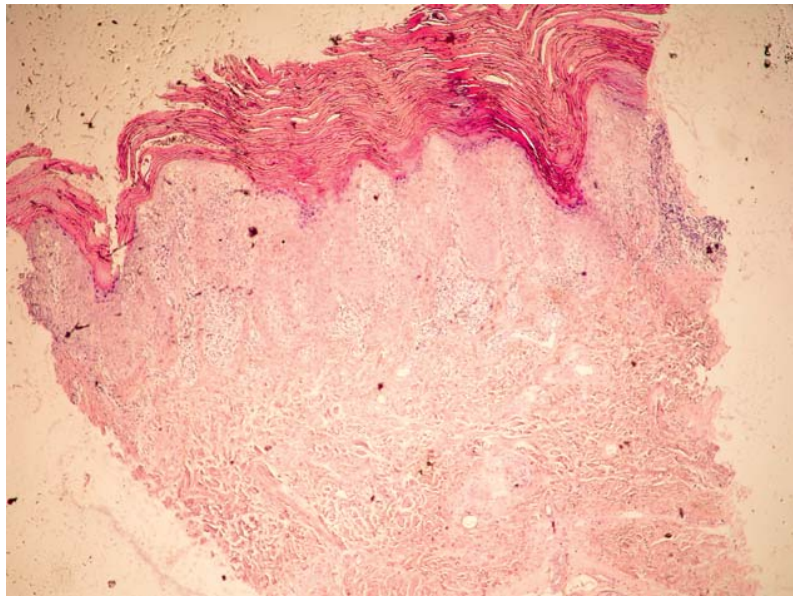

Fig. 4. Histology of irritant contact dermatitis skin lesion (punch biopsy, $H^{E} E, X 100$ ).

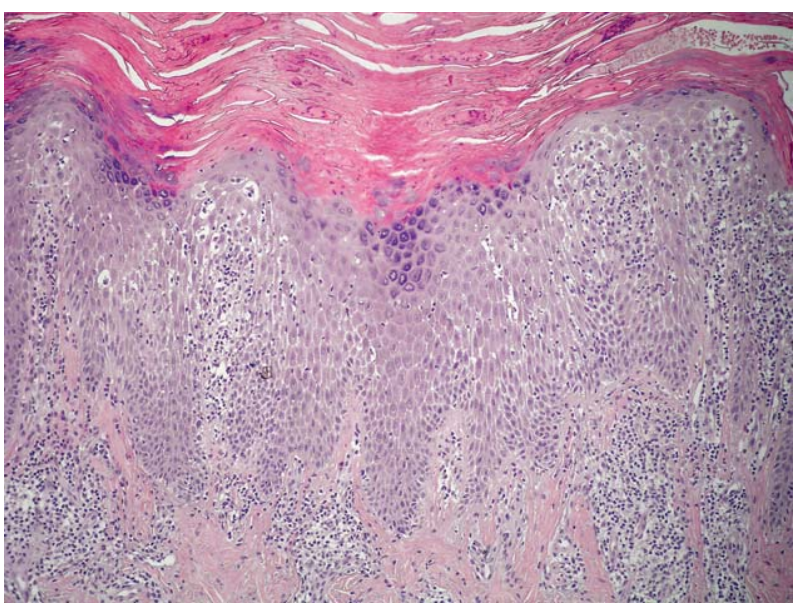

Fig. 5. Histology of irritant contact dermatitis skin lesion: acanthotic epidermis, spongiosis, spongiotic bubbles with exocytosis of lymphocytes into the spongiotic epidermis. In the subepidermal dermis, swollen capillaries and perivascular lymphocytic infiltrates are seen (HEE, X400).

hours. Skin lesions are initially asymmetric and limited to the area of contact, but often spread/disseminate later. In the case of severe reactions, there is swelling and blistering. Of the general symptoms in allergic $\mathrm{CD}$, itching is very noticeable. The major clinical differences between irritant $\mathrm{CD}$ and allergic $\mathrm{CD}$ are the more rapid onset of irritant $\mathrm{CD}$ and the tendency of allergic $\mathrm{CD}$ to spread. It is typical that the widespread reaction is usually symmetric, although the primary reaction is not.

When skin lesions of allergic $\mathrm{CD}$ persist, chronic allergic $\mathrm{CD}$ can develop (Fig. 3). Skin lesions may 
creep up subtly with no acute phase or appear on top of chronic irritant CD. Typical features include a symmetric pattern, less sharp borders, and distant spread. Also, distant lesions may occur, which are typically papulovesicular. The main feature of chronic allergic $\mathrm{CD}$ is epidermal reaction with lichenification, fissures, and pruritus ${ }^{2}$.

\section{Histologic Analysis of Contact Dermatitis Lesions}

Histologic analysis of biopsy specimens of skin lesions in irritant $\mathrm{CD}$ and allergic $\mathrm{CD}$ shows nonspecific pictures, usually including spongiosis, spongiotic bubbles, numerous neutrophils in the epidermis, swollen capillaries in the subepidermal dermis, and perivascular lymphocytic infiltrates ${ }^{29}$ (Figs. 4 and 5). Histopathology of acute irritant $\mathrm{CD}$ reveals spongiosis and vesicles or blisters in the epidermis, or sometimes epidermal necrosis or even no epidermis. In the dermis, there is a perivascular infiltrate with exocytosis of neutrophils and lymphocytes, along with vasodilatation and edema. Generally, in the cases when epidermal damage predominates, it indicates toxic damage ${ }^{2}$. However, histopathology of chronic irritant CD of the hand does not show histologic clues to the etiology of chronic irritant CD. Uncommon finding are acute changes (such as spongiosis and edema), while expected finding are reactive epidermal changes (such as lichenification), along with a dermal perivascular lymphohistiocytic infiltrate.

Histopathology of allergic CD shows lymphocytic perivascular infiltrate, high dermal edema, and epidermal spongiosis and exocytosis in the dermis ${ }^{2}$. When lesions persist in chronic allergic $\mathrm{CD}$, the epidermis shows reactive change (acanthosis, hyperkeratosis, parakeratosis) with little spongiosis and dermal mixed inflammatory infiltrate.

Histologic finding of irritant CD lesions shows moderate spongiosis, intracellular edema, exocytosis, progression of inflammatory infiltrate into the epidermis, and a reduced number of CD4+ Langerhans cells in the epidermis. Similarly, the following can be found in allergic $\mathrm{CD}$ lesions: spongiosis with predominating microvesicles, focal distribution of inflammatory infiltrate in the epidermis and sparse pustulation, and reduced numbers of CD4+ Langerhans cells that grow with time. In comparison, irritant $\mathrm{CD}$ lesions histo- logically commonly present with mild spongiosis, epidermal cell necrosis, epidermal neutrophilic infiltration, whereas in allergic CD dermal inflammatory infiltrates are predominated with lymphocytes and other mononuclear cells ${ }^{1}$.

\section{Immunohistochemistry of Contact Dermatitis Skin Lesions}

Immunohistochemical analyses are a useful research method because they enable localization of specific active antigens by use of targeted antibodies, thus providing additional information on individual diseases, including CD. In addition to diagnostic purposes, immunohistochemistry is also used in scientific research, helping us gain a better insight into the distribution and localization of biomarkers and expressions of individual proteins in various tissues ${ }^{30-32}$.

In both irritant $\mathrm{CD}$ and allergic $\mathrm{CD}$, immunohistochemistry of skin lesions shows infiltration of predominantly CD4+ T cells and some CD8+T cells. In their acute phase, there is an increased expression of IL-2, ICAM-1 and HLA-DR on keratinocytes ${ }^{33}$.

In irritant $\mathrm{CD}$ lesions, a decrease in the number of CD4+ Langerhans cells can be seen. As for allergic $\mathrm{CD}$, the number of CD4+ Langerhans cells is reduced in the beginning, but it later increases. In irritant CD and allergic $\mathrm{CD}$, the cytokines [primarily interleukins (ILs)] also have an important role in the inflammatory processes. Although the types of cytokines involved in irritant CD are somewhat different from those in allergic $\mathrm{CD}$, some cytokines are important for both types of CD. For instance, IL- 2 and IFN- $\gamma$ (generated by irritation of damaged keratinocytes) participate in the migration and activation of inflammatory cells and initiating inflammatory responses, thus participating in both CD types ${ }^{34}$. There are minor differences too; staining for IL-1 receptor antagonist is more expressed in allergic $\mathrm{CD}$ (in the dermis in a later stage), whereas IFN- $\gamma$ is more expressed in inflammatory responses in irritant $\mathrm{CD}^{35}$.

Analysis of skin biopsies in allergic CD (polymerase chain reaction and immunohistochemistry) in patients with positive patch test established higher levels of the IFN- $\gamma$, IL-4, IL-17A, IL-9 and PU.1 cytokines in comparison with normal skin. Immunohistochemically, PU.1+, CD3+, PU.1+ and CD4+ cells 
were identified in biopsies of patients with allergic CD. As regards allergic $\mathrm{CD}$, it was also established that IL-9 had a direct effect on Th1 lymphocytes, as well as on stimulation of IL-4 secretion, the regulatory role of which is important for Th1 lymphocytes ${ }^{36}$.

Thus, immune response in CD is complex and involves different cells ${ }^{1,2,15,24}$. Some studies have shown that, in allergic $\mathrm{CD}$, determining mRNA expressions for IL- $1 \beta$ has a major role in the induction phase of the disease, as it increases the expression of MHC II molecules on Langerhans cells and induces molecular adhesion [through intercellular adhesion molecule-1 (ICAM-1), vascular cell adhesion molecule-1 (VCAM-1), endothelial leukocyte adhesion molecule-1 (ELAM-1), and lymphocyte function antigen-3 (LFA-3)] $]^{15}$.

More recent studies have reported evidence that in allergic CD skin lesions, skin shows different types of reactions and different immune responses to individual allergens ${ }^{37}$. Although clinical manifestations do not depend on the causative allergen type, skin lesions show a marked immune process/polarization depending on the allergen. Thus, nickel stimulates immune activation primarily of the Th1/Th17 and Th22 components.

A recent research supports the participation of NK cells in skin lesions ${ }^{26}$. Some animal studies emphasize the role of NK cells (also called iNK T cells and Va14iNK $\mathrm{T}$ cells), which are the $\mathrm{T}$ cells that express receptors for CD161c. Thus, NK T cells recognize the glycolipids presented in the context of CD1d (MHC class I-similar molecules) and, upon activation, the Th1 and Th 2 molecules are produced, as well as IFN- $\gamma$ and IL-4 that regulate the immune response in skin lesions ${ }^{26,38}$.

\section{Conclusion}

However, although irritant and allergic CD have been studied for numerous biomarkers and factors (genetics, inflammatory mediators, antimicrobial peptides and alarmins, skin tight junctions, natural moisturizing factors, smoking, etc.), convincing, specific indicators and biomarkers have not yet been confirmed. We expect that future perspectives may reveal new pathogenetic factors and scientific data important for the workup and treatment of patients with CD.

\section{References}

1. Nair PA, Atwater AR. Dermatitis, Contact. [Updated 2017 Oct 4]. In: StatPearls [Internet]. Treasure Island (FL): StatPearls Publishing; 2017 Jun-. Available from: https://www. ncbi.nlm.nih.gov/books/NBK459230/

2. Przybilla B, Rueff F. Contact dermatitis. In: Burgdorf WHC, Plewig G, Wolf HH, Landthaler M. Braun-Falco's Dermatology. Berlin: Springer-Verlag; 2009. p. 377-401.

3. Bäsler K, Brandner JM. Tight junctions in skin inflammation. Pflugers Arch. 2017;469(1):3-14. doi: 10.1007/s00424-0161903-9.

4. Lugović L, Šitum M, Ožanić-Bulić S, Sjerobabski-Masnec I. Phototoxic and photoallergic skin reactions. Coll Antropol. 2007;31(Suppl 1):63-7.

5. Lugović-Mihić L, Duvančić T, Ferček I, Vuković P, Japundžić I, Ćesić D. Drug-photosensitivity: a continuing diagnostic challenge. Acta Clin Croat. 2017;56:277-83. doi: 10.20471/ acc.2017.56.02.11.

6. Japundžić I, Vodanović M, Lugović-Mihić L. An analysis of skin prick tests to latex and patch tests to rubber additives and other causative factors among dental professionals and students with contact dermatoses. Int Arch Allergy Immunol. 2018; 177(3):238-44. doi: 10.1159/000490181.

7. Budimir J, Mravak-Stipetić M, Bulat V, Ferček I, Japundžić I, Lugović-Mihić L. Allergic reactions in oral and perioral diseases - what do allergy skin test results show? Oral Surg Oral Med Oral Pathol Oral Radiol. 2018 Aug 18. pii: S22124403(18)31122-2. doi: 10.1016/j.oooo.2018.08.001.

8. Bakula A, Lugović-Mihić L, Šitum M, Turčin J, Šinković A. Contact allergy in the mouth: diversity of clinical presentations and diagnosis of common allergens relevant to dental practice. Acta Clin Croat. 2011;50(4):553-61.

9. Japundžić I, Lugović-Mihić L. Skin reactions to latex in dental professionals - first Croatian data. Int J Occup Saf Ergon. 2017;5:1-20. doi: 10.1080/10803548.2017.1388026.

10. Japundžić I, Novak D, Kuna M, Novak-Bilić G, LugovićMihić L. Analysis of dental professionals' and dental students' care for their skin. Acta Stomatol Croat. 2018;52(1);46-52. doi: 10.15644/asc52/1/7.

11. Lugović-Mihić L, Pilipović-Knežević K, Crnaric I, Šitum M, Duvančić T. Differential diagnostics of cheilitis..How to classify cheilitis? Acta Clin Croat. 2018;57:1-10. doi: 10.20471/ acc.2018.57.02.16.

12. Angelova-Fischer I, Stilla T, Kezic S, Fischer TW, Zillikens D. Barrier function and natural moisturizing factor levels after $\mathrm{cu}^{-}$ mulative exposure to short-chain aliphatic alcohols and detergents: results of occlusion-modified tandem repeated irritation test. Acta Derm Venereol. 2016;96(7):880-4. doi: 10.2340/00015555-2363.

13. Mostosi C, Simonart T. Effectiveness of barrier creams against irritant contact dermatitis. Dermatology (Basel). 2016;232(3): 353-62. doi: 10.1159/000444219. 
14. Elentner A, Schmuth M, Yannoutsos N, Eichmann TO, Gruber R, Radner FPW, et al. Epidermal overexpression of xenobiotic receptor PXR impairs the epidermal barrier and triggers Th2 immune response. J Invest Dermatol. 2017 Sep 18. pii: S0022-202X(17)32824-5. doi: 10.1016/j.jid.2017.07.846.

15. Wahbi A, Marcuson JA. Sunquist KG. Expression of adhesion molecules and their ligands in contact allergy. Exp Dermatol. 1996;5(1):12-9.

16. Vocanson M, Hennino A, Rozières A, Poyet G, Gaillard V, Renaudineau $\mathrm{S}$, et al. Effector and regulatory mechanisms in allergic contact dermatitis. Allergy. 2009;64(12):1699-714. doi: 10.1111/j.1398-9995.2009.02082.x.

17. Lehé CL, Jacobs JJ, Hua CM, Courtellemont P, Elliott GR, Das PK. Subtoxic concentrations of allergenic haptens induce LC migration and maturation in a human organotypic skin explant culture model: a novel method for identifying potential contact allergens. Exp Dermatol. 2006;15(6):421-31.

18. Gawkrodger DJ, McVittie E, Carr MM, Ross JA, Hunter JA. Phenotypic characterization of the early cellular responses in allergic and irritant contact dermatitis. Clin Exp Immunol. 1986;66:590-8.

19. Saint-Mezard P, Rosieres A, Krasteva M, Berard F, Dubois B, Kaiserlian D, et al. Allergic contact dermatitis. Eur J Dermatol. 2004;14(5):284-95.

20. Saint-Mezard P, Berard F, Dubois B, Kaiserlian D, Nicolas JF. The role of CD4+ and CD8+ T cells in contact hypersensitivity and allergic contact dermatitis. Eur J Dermatol. 2004;14(3): 131-8.

21. Man M, Elias PM, Man W, Wu Y, Bourguignon LY, Feingold $\mathrm{KR}$, Man MQ. The role of CD44 in cutaneous inflammation. Exp Dermatol. 2009;18(11):962-8. doi: 10.1111/j.1600-0625.2009.00882.x.

22. Rundle CW, Bergman D, Goldenberg A, Jacob SE. Contact dermatitis considerations in atopic dermatitis. Clin Dermatol. 2017;35(4):367-74. doi: 10.1016/j.clindermatol.2017.03.009.

23. Heede NG, Thyssen JP, Thuesen BH, Linneberg A, Szecsi PB, Stender $\mathrm{S}$, et al. Health-related quality of life in adult dermatitis patients stratified by filaggrin genotype. Contact Dermatitis. 2017;76(3):167-77. doi: 10.1111/cod.12731.

24. Koppes SA, Engebretsen KA, Agner T, Angelova-Fischer I, Berents T, Brandner J, et al. Current knowledge on biomarkers for contact sensitization and allergic contact dermatitis. Contact Dermatitis. 2017;77(1):1-16. doi: 10.1111/cod.12789.

25. Zimmer KA, Armbrecht ES, Burkemper NM. The association of smoking with contact dermatitis and hand eczema - a review. Int J Dermatol. 2017 Sep 27. doi: 10.1111/ijd.13777.

26. Kumagai K, Horikawa T, Shigematsu H, Matsubara R, Kitaura $\mathrm{K}$, Eguchi T, et al. Possible immune regulation of natural killer $\mathrm{T}$ cells in a murine model of metal ion-induced allergic contact dermatitis. Int J Mol Sci. 2016;17(1). pii: E87. doi: 10.3390/ ijms17010087.

27. Dombrowski Y, Koglin S, Ruzicka T, Schauber J. Alarmins and their role in inflammatory skin diseases. Akt Dermatol. 2010;36(12):467-70. doi: 10.1055/s-0030-1255865.

28. Wang J, Suárez-Fariñas M, Estrada Y, Parker ML, Greenlees L, Stephens G, et al. Identification of unique proteomic signatures in allergic and non-allergic skin disease. Clin Exp Allergy. 2017;47(11):1456-67. doi: 10.1111/cea.12979.

29. Gru AA, Salavaggione AL. Common spongiotic dermatoses. Semin Diagn Pathol. 2017;34(3):226-36. doi: 10.1053/j.semdp.2017.02.002.

30. Ulfgren AK, Klareskog L, Lindberg M. An immunohistochemical analysis of cytokine expression in allergic and irritant contact dermatitis. Acta Derm Venereol. 2000;80(3):167-70.

31. Lugović L, Lipozenčić J, Jakić-Razumović J. Atopic dermatitis: immunophenotyping of inflammatory cells in skin lesions. Int J Dermatol. 2001;40:489-94.

32. Lugović L, Lipozenčić J, Jakić-Razumović J. Prominent involvement of activated Th1-subset of T-cells and increased expression of receptor for IFN-gamma on keratinocytes in atopic dermatitis acute skin lesions. Int Arch Allergy Immunol. 2005;137(2):125-33.

33. Gerberick GF, Rheins LA, Ryan CA, Ridder GM, Haren M, Miller C, et al. Increases in human epidermal DR+CD1+, DR+ CD1-CD36+, and DR-CD3+ cells in allergic reactions versus irritant patch test reactions. J Invest Dermatol. 1994;103(4): 524-9.

34. Hoefakker S, Caubo M, van't Erve EH, Roggeveen MJ, Boersma WJ, van Joost T, et al. In vivo cytokine profiles in allergic and irritant contact dermatitis. Contact Dermatitis. 1995;33 (4):258-66.

35. Pichowski JS, Cumberbatch M, Basketter DA, Kimber I. Investigation of induced changes in interleukin 1beta mRNA expression by cultured human dendritic cells as in vitro approach to skin senzitization testing. Toxicol In Vitro. 2000;14 (4):351-60.

36. Liu J, Harberts E, Tammaro A, Girardi N, Filler RB, Fishelevich R, et al. IL-9 regulates allergen-specific Th1 responses in allergic contact dermatitis. J Invest Dermatol. 2014;134(7): 1903-11. doi: 10.1038/jid.2014.61.

37. Dhingra N, Shemer A, Correa da Rosa J, Rozenblit M, Fuentes-Duculan J, et al. Molecular profiling of contact dermatitis skin identifies allergen-dependent differences in immune response. J Allergy Clin Immunol. 2014;134(2):362-72. doi: 10.1016/j.jaci.2014.03.009

38. Taniguchi M, Harada M, Kojo S, Nakayama T, Wakao H. The regulatory role of Valpha $14 \mathrm{NKT}$ cells in innate and acquired immune response. Annu Rev Immunol. 2003;21:483-513. 


\title{
Sažetak
}

\section{IRITATIVNI I ALERGIJSKI KONTAKTNI DERMATITIS - OBILJEŽJA LEZIJA KOŽE}

\author{
G. Novak-Bilić, M. Vučić, I. Japundžić, J. Meštrović-Štefekov, S. Stanić-Duktaj i L. Lugović-Mibić
}

Kontaktne reakcije kože mogu biti posljedice kontakta s različitim iritansima ili alergenima ili mogu nastati zbog drugih čimbenika (npr. UV zračenja, mikroorganizama), unutarnjih čimbenika (npr. kod autoimunih reakcija) ili njihovom kombinacijom. Postoje mnoge tvari koje su povezane s pojavom iritativnog kontaktnog dermatitisa (KD) te uzrokuju iritativne ili toksične učinke: kemijske i fizikalne tvari, biljke, fototoksične tvari, okolišni čimbenici itd. Također oštećena funkcija kožne barijere (npr. odstupanja u epidermalnim $\mathrm{pH}$ puferskim sposobnostima) sudjeluje u tome promicanjem bakterijskih biofilmova i stvaranjem okruženja koja pogoduju senzibilizaciji. Razvoj kožnih oštećenja kod alergijskog KD-a obuhvaća kompleksne imunosne puteve i upalne medijatore koji su pod utjecajem i genetskih čimbenika (pretežno mutacija filagrina) i okidača iz okoliša. U patogenezi alergijskog $\mathrm{KD}$-a istaknuta je uloga antimikrobnih peptida koji nastaju kao proizvod različitih kožnih stanica (npr. keratinociti, sebociti) i potom prelaze u kožne lezije tijekom procesa upale. Također, kod kožnih lezija u alergijskom KD-u koža pokazuje različite tipove imunosnih odgovora na pojedine alergene, iako kliničke manifestacije ne ovise o vrsti uzročnog alergena; npr. nikal stimulira imunosnu aktivaciju prvenstveno Th1/Th17 i Th22 komponenata. Također su važni alarmini, proteaze, imunoproteomi, lipidi, prirodni hidratantni čimbenici, međustanične veze, pušenje itd. Očekujemo da će se istraživanjima u budućnosti otkriti novi patogenetski čimbenici i znanstvene spoznaje važne za rad i liječenje bolesnika s KD-om.

Ključne riječi: Dermatitis, alergijski kontaktni; Dermatitis, iritativni; Upala kože; Etiopatogeneza; Imunohistokemija; Histologija; Čimbenici 